\section{SEA LEVEL ANOMALY ASSESSMENT OF SARAL/ALTIKA MISSION USING HIGH AND LOW RESOLUTION DATA}

Goh Sheng Howa, Ami Hassan Md Dina,b*, Mohammad Hanif Hamdena, Mat Nizam Utia, Nadia Hartini Mohd Adzmic

aGeomatics Innovation Research Group (GnG), bGeoscience and Digital Earth Centre (INSTEG), Faculty of Built Environment and Surveying, Universiti Teknologi Malaysia, 81310 UTM Johor Bahru, Johor, Malaysia

'UTM-Centre for Industrial and Applied Mathematics (UTM-CIAM), Universiti Teknologi Malaysia, 81310 Johor Bahru, Johor, Malaysia
Article history

Received

30 May 2019

Received in revised form

5 May 2020

Accepted

16 May 2020

Published online

22 June 2020

*Corresponding author amihassan@utm.my
Graphical abstract

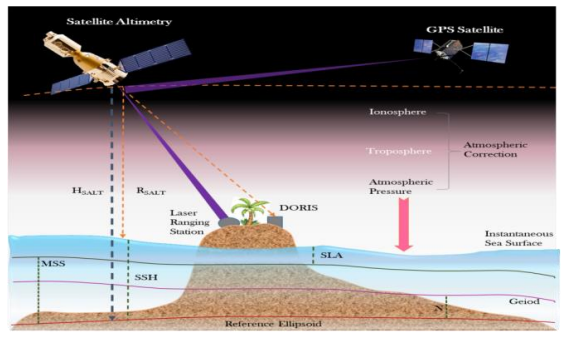

\section{Abstract}

Peninsular Malaysia is located at the focal point of Sunda Shelf, encompassed by the South China Sea to the East and by Andaman Sea at Indian Ocean in the west that causes various phenomena relevant to sea level along Malaysian coast. When the monsoons strike, the effect of wind and other factors will change the variability of Sea Level Anomaly (SLA) along coastal Malaysia. Traditionally, sea level change is observed using tide gauge installed along Malaysian coastal area. However, the data obtained is limited to the tide gauge station area, the sea level data for the deep sea cannot be obtained and there is no long-term record of observation. Therefore, satellite altimeter is used as a new alternative which enables sea level data to be obtained from space observation and to monitor SLA via SARAL/AltiKa which available since 2013, thus complementing the tide gauge. The aim of this study is to derive SLA parameter from high and low resolution of satellite altimetry data. This study involved the acquisition of SLA data by using RADS and PEACHI (AVISO) database system from satellite mission SARAL/AltiKa. Sequentially, SLA data has been analysed and evaluated based on tide gauge data provided by using UHSLC system. Comparison between the high resolution (PEACHI) and low resolution (RADS) data has been made to evaluate the density of altimetry data in term of distance to coast. As a result, high resolution (PEACHI) data are more accurate for coastal application with root mean square error (RMSE) of \pm 0.14 metre level. The analysis shows that the footprint of high resolution altimetry data is denser than the Iow resolution altimetry data. Data from distance to coast for PEACHI achieved a satisfactory standard deviation of residual, which is ranged between $0 \mathrm{~cm}$ to 1.04 $\mathrm{cm}$ as compared to altimetry RADS which is ranged $0.34 \mathrm{~cm}$ to $12.57 \mathrm{~cm}$. The results can be used by various agencies in planning and developing Malaysian coastal areas as well as in assisting the development of community economies such as fishery and tourism activities.

Keywords: Sea level anomaly, high resolution, low resolution, satellite altimeter, distance to coast 


\begin{abstract}
Abstrak
Semenanjung Malaysia terletak di titik tumpuan Sunda Shelf, yang dikelilingi oleh Laut China Selatan ke Timur dan Laut Andaman di Lautan Hindi di barat yang menyebabkan pelbagai fenomena yang relevan dengan paras laut di sepanjang pantai Malaysia. Apabila berlaku mogok monsun, kesan angin dan faktor-faktor lain akan mengubah anomali paras laut di sepanjang pantai Malaysia. Secara tradisinya, perubahan paras laut diukur dengan menggunakan tolok pasang surut yang dipasang di kawasan pantai Malaysia. Walau bagaimanapun, data yang diperoleh adalah terhad kepada stesen tolok pasang surut, data paras laut untuk laut yang dalam tidak dapat diperoleh dan tiada rekod pengukuran bagi jangka masa yang panjang. Oleh itu, satelit altimeter digunakan sebagai alternatif baru yang membolehkan data paras laut diperoleh daripada pengukuran dari ruang angkasa dan memantau anomali paras laut (SLA) melalui SARAL/AltiKa yang boleh didapati sejak tahun 2013, dengan itu melengkapkan tolok pasang surut. Objektif kajian ini adalah untuk mendapatkan parameter SLA daripada data altimetri satelit yang resolusi tinggi dan rendah. Kajian ini melibatkan pemerolehan data SLA dengan menggunakan sistem pangkalan data RADS dan PEACHI (AVISO) dari misi satelit SARAL/AltiKa. Secara serentak, data SLA telah dianalisis dan dinilai berdasarkan data tolok pasang surut yang dibekalkan dengan menggunakan sistem UHSLC. Perbandingan antara resolusi tinggi (PEACHI) dan resolusi rendah (RADS) data juga dibuat untuk menilai kepadatan dalam pengukuran jarak ke pantai. Berdasarkan hasil yang diperoleh, ditunjukkan bahawa data resolusi tinggi (PEACHI) lebih tepat untuk aplikasi kawasan pantai dengan RMSE \pm 0.14 meter. Hasil analisis menunjukkan bahawa jejak data altimetri resolusi tinggi jauh lebih padat daripada data altimetri yang resolusi rendah kerana jumlah jejak dalam RADS adalah 10 hingga 11 dan jumlah jejak di PEACHI adalah 469 untuk jarak ke pantai dalam lingkungan $80 \mathrm{~km}$. Data jarak ke pantai untuk altimetri PEACHI mencapai sisihan piawai yang memuaskan iaitu berjulat antara $0 \mathrm{~cm}$ hingga $1.04 \mathrm{~cm}$ apabila dibandingkan dengan RADS altimetri yang berjulat antara $0.34 \mathrm{~cm}$ hingga 12.57 $\mathrm{cm}$. Hasil kajian ini dapat digunakan oleh pelbagai agensi dalam perancangan dan pembangunan di kawasan pantai Malaysia serta dapat membantu pembangunan ekonomi masyarakat seperti kegiatan perikanan dan pelancongan.
\end{abstract}

Kata kunci: Anomali paras laut, resolusi tinggi, resolusi rendah, satellite altimeter, jarak ke pantai

(C) 2020 Penerbit UTM Press. All rights reserved

\subsection{INTRODUCTION}

Numerous experience related to sea level along the Malaysian coastal is happened due to the strategic location of Peninsular Malaysia that is situated between South China Sea and Malacca Straits [1], [2]. The consequence of wind and other factors will alter the variability of Sea Level Anomaly (SLA) along the coast of Malaysia when the monsoons hit. Coastal currents as well as tides are useful to understand the coastal dynamics such as fishing, navigation of ships, construction of bridges, docks, etc [3]. Sea level changes is traditionally measured by utilising tide gauge station [4], [5]. However, satellite altimetry presently offers the best opportunity for upgrading our knowledge of sea level, with better accuracy of measurement. Due to irregular geographical characteristic of installed tide gauge stations at coastal areas, affected by vertical movement due to active tectonic activities in the region and the lack of deep ocean long term tide records, there is a gap in monitoring sea level changes for Malaysian region [6].
Thus, as an alternative method from traditional tide gauge station, satellite altimeter can be used to solve the gap problem in monitoring sea level changes. Satellite altimeter is one of the basic instruments for furnishing observations of the worldwide oceans with unprecedented accuracy in absolute sea level measurement of temporal sampling from few hours up to month. It can be used as an alternative for monitoring sea level anomaly especially for deep ocean in Malaysian seas rather than using discrete tide gauges that are very difficult to install in deep ocean. This study also important to show the accuracy and reliability of satellite altimeter to replace the traditional tide gauge and the variability of sea level anomaly.

Over decades, satellite radar altimetry has been used for revising global oceans and climate changes using radar band. SARAL/AltiKa is a new generation of satellite altimetry that equipped with wide $\mathrm{Ka}$ band altimeter (35.75 GHz). SARAL/AltiKa satellite altimetry can produce finer spatial resolution of $40 \mathrm{~Hz}$ data which corresponds to $\sim 200 \mathrm{~m}$ along-track sampling [7]. 
The SARAL/AltiKa altimeter is able to resolve SLA signals of more than $2 \mathrm{~cm}$, and gradients in those signals over several tens of kilometres. After filtering, the $40 \mathrm{~Hz}$ data depicted a signal consistent with the other platforms, up to a distance of order $10 \mathrm{~km}$ from the coast [8]. Other than high resolution $(40 \mathrm{~Hz})$ technique, there is also other technique by using low resolution with $1 \mathrm{~Hz}$ data. The error is propagated along track because of the size and shape of the low resolution mode (LRM) disc-shaped footprint [9]. The aim of this paper is to assess the sea level anomaly (SLA) from SARAL/AltiKA using high and low resolution data and to evaluate the SLA variability with respect to distance to the coast. This study also assessed the accuracy of SLA by comparing with tidal data.

\subsection{Principle of Satellite Altimeter}

Satellite altimetry is a technique for observing the Earth and its oceans from Space. The principle is to precisely measure a satellite's altitude and then the distance between the satellite and the target surface. By calculating the difference between the two, 'sea level anomaly' is obtained after eliminating the range and geophysical corrections. This sea level anomaly can be used to understand a vast amount of information about the ocean and its movements. With systems such as Doppler Orbitography and Radio Positioning Integrated by Satellite (DORIS) and GPS, which measure the satellite's position extremely accurately, sea level anomaly can be calculated to within just a few centimetres. Altimetry can also determine wave height and wind speed on the ocean, as well as surface height for lakes and rivers, information about the Earth's gravity field, sea ice and polar ice cap topography [10].

The basic principle of satellite altimeter is based on the simple fact that time is a distance. The distance between the satellite and the sea surface is measured from the round-trip travel time of microwave pulses emitted downward by the satellite radar, reflected back from the ocean, and received again on board. Meanwhile, the independent tracking systems are used to compute the satellite's three-dimensional position relative to a fixed Earth coordinate system. By combining these two measurements yields profiles of sea surface height, or sea level, with respect to the reference ellipsoid [11].

However, the situation is far more complex in practice. Several factors have to take into account such as instrument design, calibration, validation, range corrections (ionosphere, troposphere and sea state bias), geophysical corrections (tides, geoid and inverse barometer), reference systems, precise orbit (satellite height) determination, different satellites with different sampling characteristics, and so on. Figure 1 presents the schematic diagram of satellite radar altimeter system and its principle. By using a similar notation to [12], the corrected range Rcorrected is related to the observed range Robs as:

$$
R_{\text {corrected }}=R_{\text {obs }}-\Delta R_{\text {dry }}-\Delta R_{\text {wet }}-\Delta R_{\text {iono }}-\Delta R_{s s b}
$$

Where,

$R_{o b s}=c \frac{t}{2}$ is the computed range from the travel time $t$ observed by the on-board ultra-stable oscillator (USO), and $c$ is the speed of the radar pulse neglecting refraction

$\Delta R_{d r y}:$ Dry tropospheric correction

$\Delta R_{\text {wet }}$ : Wet tropospheric correction

$\Delta R_{\text {iono }}$ : Ionospheric correction

$\Delta R_{s s b}:$ Sea-state bias correction

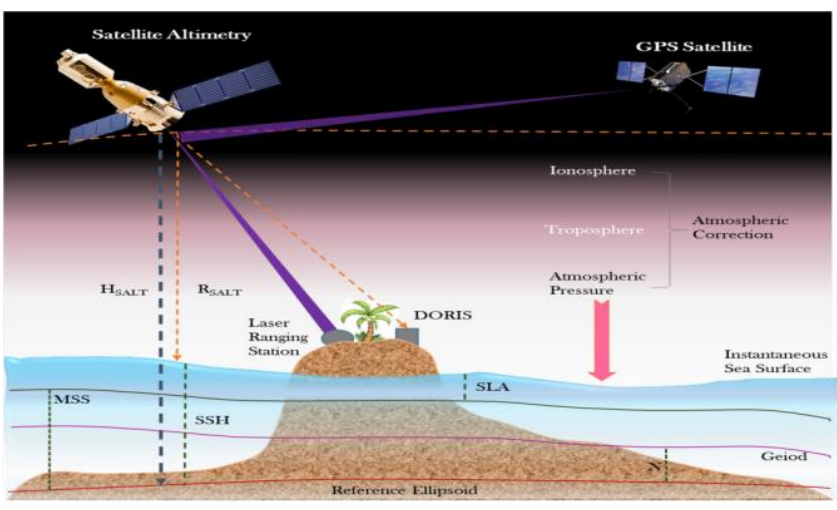

Figure 1 Principle of Satellite Altimeter

The range measurement is then converted to the sea surface height (SSH), h of the sea surface relative to the reference ellipsoid and given as:

$h=H-R_{\text {corrected }}=H-\left(R_{\text {obs }}-\Delta R_{\text {dry }}-\Delta R_{\text {wet }}-\Delta R_{\text {iono }}-\Delta R_{s s b}\right)$

Where,

$H$ : The height of the spacecraft determined through orbit determination

Then, sea level anomaly (SLA) from altimetry data can be obtained by applying the geophysical corrections on the previously derived sea surface height, $h$. It notes that the geophysical corrections consist of atmospheric pressure loading, mean sea surface (MSS) model and tidal corrections such as ocean tide, load tide, pole tide and solid earth tide.

Next, the Brown mathematical model is the standard model for waveform retracking over open ocean, due to heterogeneous surface reflections within altimeter footprints, coastal waveforms usually deviate from open ocean waveform shapes and thus cannot be directly interpreted by the Brown model [13]. Generally, the two primary sources of heterogeneous surface reflections are land surfaces and bright targets such as calm surface water [14]. 
The formulation of the theoretical shape of an echo over an ocean surface was given by Brown and refined by Hayne [15] to include a fixed skewness parameter, $\lambda_{s}$. This is the model implemented for example as the Ocean-1 retracker on Envisat RA-2 [15]. The analytical formula reads:

$$
\begin{gathered}
V_{m}(t)=T_{n}+a_{\xi} \frac{P_{u}}{2} \exp (-v) \\
\left\{[1+\operatorname{erf}(u)]+\frac{\lambda_{s}}{6}\left(\frac{\sigma_{s}}{\sigma_{c}}\right)^{2}\left\{[1+\operatorname{erf}(u)] c_{\xi}^{3} \sigma_{c}^{3}-\frac{\sqrt{2}}{\sqrt{\pi}}\left[2 u^{2}+3 \sqrt{2} c_{\xi} \sigma_{c} u+3 c_{\xi}^{2} \sigma_{c}^{2}-1\right] \exp \left(-u^{2}\right)\right\}\right\}
\end{gathered}
$$

with $c$ the velocity of light, $h$ the satellite altitude, $R_{e}$ the Earth radius, SWH the significant wave height (= $\left.2 c \sigma_{s}\right), \xi$ the off-nadir mispointing angle, and $\theta_{0}$ the antenna beam width. Figure 2 shows a representation of a typical ocean waveform with the corresponding parameters that can be retrieved. The waveform is characterised by:

- $\quad t$ the epoch or time delay i.e. the position of the waveform in the analysis window, with respect to the nominal tracking reference point.

- $\sigma_{s}$ the slope of the leading edge which relates to the significant wave height (SWH).

- $\quad P_{u}$ the amplitude of the signal, which relates to the backscatter coefficient $\left(\sigma_{0}\right)$.

- $\quad T_{n}$ the thermal noise level usually estimated from an arithmetic average of waveform samples from the noise floor plateau before the leading edge.

- Other parameters, such as the altimeter mispointing $(\xi)$ and skewness $\left(\lambda_{s}\right)$.

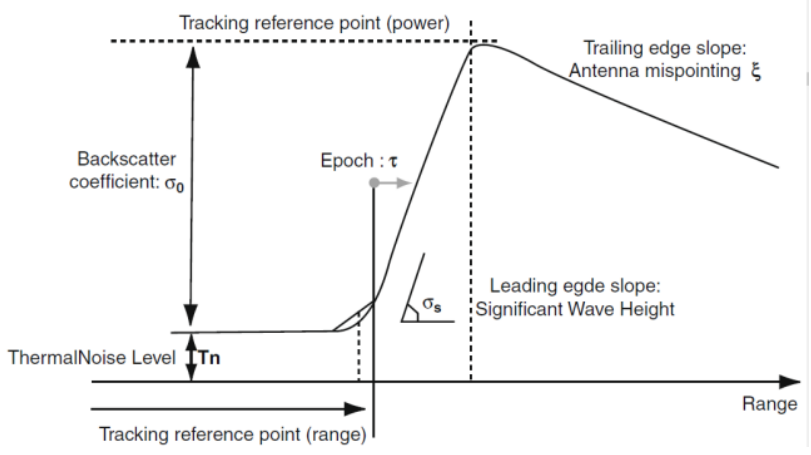

Figure 2 Theoretical Brown ocean waveform shape and corresponding retrieved ocean parameters [15]

\subsection{Low and High Resolution Data}

RADS and PEACHI (AVISO) system can provide high and low resolution data which would be a revealing comparison over the accuracy for coastal area. With RADS system, the low resolution data $(1 \mathrm{~Hz})$ could be acquire at $\sim 7 \mathrm{~km}$ for every footprint interval. Meanhile, PEACHI system provides high resolution data $(40 \mathrm{~Hz})$ at $\sim 200 \mathrm{~m}$ for every footprint interval.
Table 1 shows the comparison between two difference types of resolution.

Table 1 Comparison between the two-difference type of resolution

\begin{tabular}{ccccc}
\hline No & Altimetry & Resolution & $\begin{array}{c}\text { Frequency } \\
(\mathbf{H z})\end{array}$ & $\begin{array}{c}\text { Footprint } \\
\text { Interval } \\
(\mathbf{k m})\end{array}$ \\
\hline $\mathbf{1}$ & RADS & Low & 1 & $\sim 7$ \\
$\mathbf{2}$ & PEACHI & High & 40 & $\sim 0.2$ \\
\hline
\end{tabular}

\subsection{METHODOLOGY}

In this study, satellite altimetry data has been processed and retrieved from Radar Altimeter Database System (RADS) and Prototype for Expertise on AltiKa for Coastal, Hydrology and Ice (PEACHI) via Archiving, Validation and Interpretation of Satellite Oceanographic (AVISO) website.

\subsection{Study Area}

The study area is focused on east coast of Peninsula Malaysian sea which is limited between latitude from $1^{\circ}$ until $7^{\circ}$ and longitude from $102^{\circ}$ until $106^{\circ}$ as shown in Figure 3 and 4.

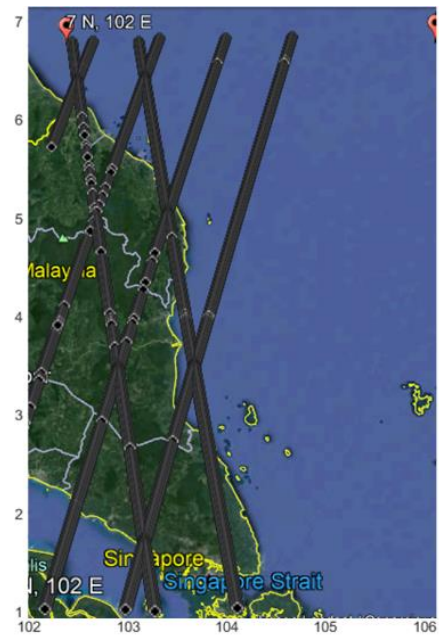

Figure 3 Study area of east coast of Peninsula Malaysian sea for PEACHI [16] 


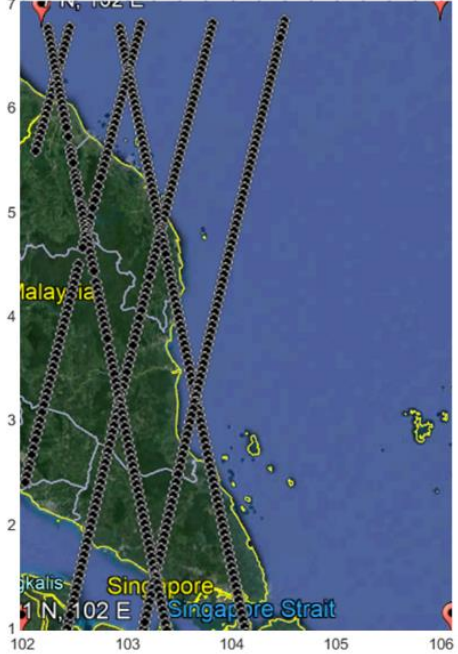

Figure 4 Study area of east coast of Peninsula Malaysian sea for RADS [16]

\subsection{Altimetry Data Sources}

One satellite altimeter mission is selected in this study which is Saral/Altika for deriving the sea level anomaly. The period of this satellite altimetry data is one year, from $1^{\text {st }}$ January 2014 to $31^{\text {st }}$ December 2014.

\subsubsection{Radar Altimeter Database System (RADS)}

RADS is used to process and derive the sea level anomaly data [17]. RADS enable user to define suitable corrections applied to their data. RADS also able to provide data collection with low resolution (1 $\mathrm{Hz}$ ) at $\sim 7 \mathrm{~km}$ footprint interval. For more details, user can visit to the RADS website http://rads.tudelft.nl/rads/rads.shtml as shown in Figure 5. In RADS website, user can define their specific geographical region using coordinate and other related parameter.

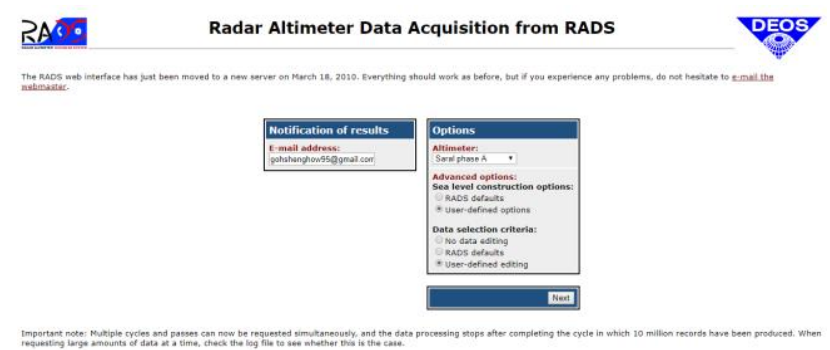

Figure 5 Radar Altimeter Database System (RADS) homepage [17]

\subsubsection{Prototype for Expertise on AltiKa for Coastal, Hydrology and Ice (PEACHI)}

Archiving, Validation and Interpretation (AVISO) can be used to process and retrieve the sea level anomaly data. Under AVISO database, there is an experimental SARAL products, namely, Prototype for Expertise on Altika for Coastal, Hydrology and Ice (PEACHI). These products are running by CLS in the framework of the PEACHI project. The PEACHI processing is used L2P products. The L2P products are along track products that contain time, sea level anomaly, information of validity of the data and all corrections which are necessary to compute the sea level anomaly. These products contain only marine surfaces. They have a homogenized format and content for all altimeter missions. Figure 6 shows processing steps of the system.

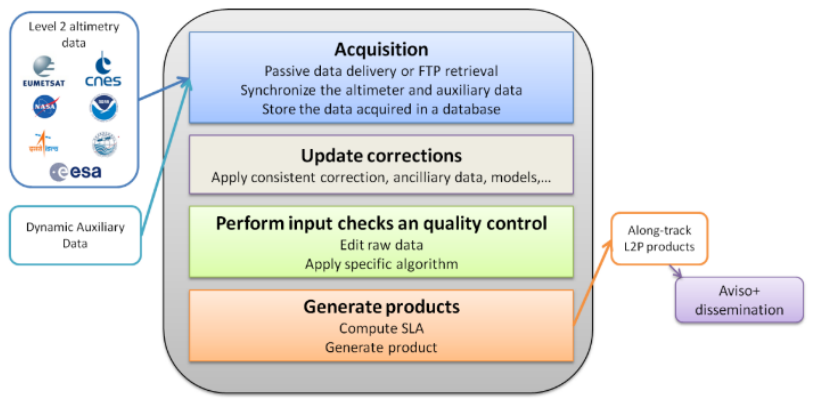

Figure 6 Processing steps of the system [18]

Moreover, these products can enable user to define suitable corrections applied to their data as well as enable to provide high resolution $(40 \mathrm{~Hz})$ data collection at $\sim 200 \mathrm{~m}$ footprint interval. User can visit to the website which is https://www.aviso.altimetry.fr/en/data/productinformation/aviso-user-handbooks.html for more details. In this website user also can define their specific geographical region using coordinate and other related settings as shown in Figure 7.

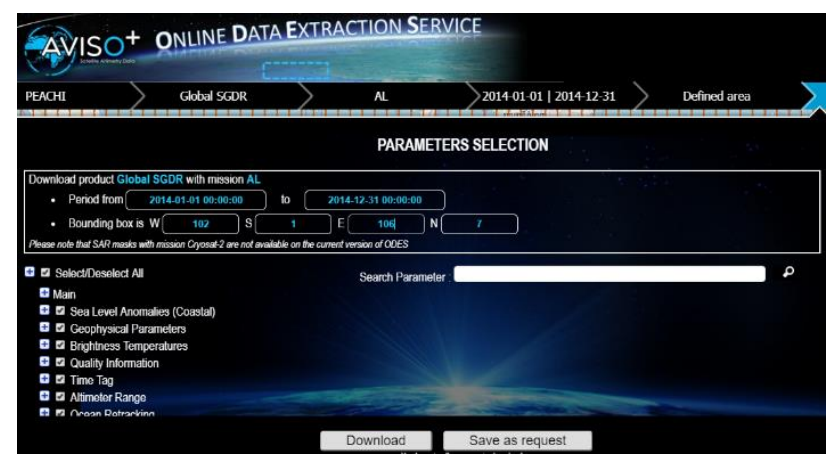

Figure 7 Archiving, Validation and Interpretation (AVISO) homepage [19] 


\subsubsection{Tide Gauge Data}

University of Hawaii Sea Level Center (UHSLC) has been responsible for the gathering, distribution, analysis and interpretation of sea level data from the worldwide network of tide gauge. In this study, hourly tidal data has been retrieved from UHSLC. There are 2 tide gauge stations selected in this study for the validation purpose. In this study, sea level from satellite altimeter is compared with tidal data by extracting hourly sea level anomaly at the tide gauge locations and the altimeter track that are close by the tide gauge station. The period of data begins from $1^{\text {st }}$ January 2014 until $31^{\text {st }}$ December 2014. Subsequently, the pattern and relationship of sea level anomalies from both measurements were assessed. However, to deliver a comparable outcome, the period must be the same in each area. Figure 8 shows UHSLC website where the tide gauge information has been acquired. Two (2) tide gauge stations are selected for the validation purpose; Geting and Cendering. Sea level data from satellite altimeter is analysed with tidal data from tide gauge stations by extracting hourly sea level anomaly at the closest altimeter track from the tide gauge station. Subsequently, the sea level anomalies pattern and relationship from both measurements have been assessed. Table 2 shows the geographical location of tide gauge for the validation purpose.

Table 2 List of tide gauge station selected

\begin{tabular}{lllc}
\hline \multirow{2}{*}{ No. } & \multirow{2}{*}{ Station } & Latitude & $\begin{array}{c}\text { Location } \\
\text { Longitude }\end{array}$ \\
\hline 1 & Geting & $6^{\circ} 03^{\prime} 35^{\prime \prime}$ & $102^{\circ} 06^{\prime} 24^{\prime \prime}$ \\
2 & Cendering & $5^{\circ} 15^{\prime} 54^{\prime \prime}$ & $103^{\circ} 11^{\prime} 12^{\prime \prime}$ \\
\hline
\end{tabular}

\begin{tabular}{|c|c|c|c|c|c|c|c|c|c|c|}
\hline s & & & VEL & ENTER & Fast Delit & & Research & Quality & & EDAP \\
\hline 140 & & a & Kelang & Malaysia & 3.05000 & 101.35800 & $\begin{array}{l}1983- \\
12-16\end{array}$ & $\begin{array}{l}2015- \\
12-31\end{array}$ & $\begin{array}{l}\text { dalily } \\
\text { hourly }\end{array}$ & $\begin{array}{l}\text { dally } \\
\text { houry }\end{array}$ \\
\hline 141 & & a & Keling & Malaysia & 2.21500 & 102.15300 & $\begin{array}{l}1984 . \\
11-07\end{array}$ & $\begin{array}{l}2015- \\
12-31\end{array}$ & $\begin{array}{l}\text { daily } \\
\text { hourly }\end{array}$ & $\begin{array}{l}\text { daily } \\
\text { hourly }\end{array}$ \\
\hline 142 & & a & Langkawi & Malaysia & 6.43200 & 99.76500 & $\begin{array}{l}1985- \\
11-30\end{array}$ & $\begin{array}{l}2018- \\
12-31\end{array}$ & $\begin{array}{l}\text { dally } \\
\text { hourly }\end{array}$ & $\begin{array}{l}\text { daily } \\
\text { hourly }\end{array}$ \\
\hline 143 & 043 & a & Lumut & Malaysia & 4.24000 & 100.61300 & $\begin{array}{l}1984 \\
12-13\end{array}$ & $\begin{array}{l}2015- \\
12-31\end{array}$ & $\begin{array}{l}\text { daily } \\
\text { hourly }\end{array}$ & $\begin{array}{l}\text { daily } \\
\text { hourly }\end{array}$ \\
\hline 144 & & a & Penang & Malaysia & 5.42200 & 100.34700 & $\begin{array}{l}1984 \\
11-16\end{array}$ & $\begin{array}{l}2015- \\
11-12\end{array}$ & $\begin{array}{l}\text { dally } \\
\text { houry }\end{array}$ & $\begin{array}{l}\text { dally } \\
\text { hourty }\end{array}$ \\
\hline 320 & 293 & a & Cendering & Malaysia & 5.26500 & 103.18700 & $\begin{array}{l}1984 \\
11-01\end{array}$ & $\begin{array}{l}2015- \\
11-30\end{array}$ & $\begin{array}{l}\text { daily } \\
\text { hourly }\end{array}$ & $\begin{array}{l}\text { daily } \\
\text { hourly }\end{array}$ \\
\hline 321 & & a & Johor Baharu & Malaysia & 1.46200 & 103.79200 & $\begin{array}{l}1983-2- \\
12-19\end{array}$ & $\begin{array}{l}2013- \\
12-31\end{array}$ & $\begin{array}{l}\text { dalily } \\
\text { houry }\end{array}$ & $\begin{array}{l}\text { dally } \\
\text { hourty }\end{array}$ \\
\hline
\end{tabular}

Figure 8 University of Hawaii Sea Level Center [20]

\subsection{RESULTS AND DISCUSSION}

This section analyses and discusses the sea level anomaly results from satellite altimeter and tide gauge. It is divided into several sub-sections which are sea level anomaly data verification, sea level variation in relating to distance to coast, sea level variation due to seasonal effect and analysis of altimetry data density.

\subsection{Data Verification: Altimeter vs Tide gauge}

Data verification from hourly altimetry and tidal solution is performed using the time series pattern and the correlation analysis of sea level anomalies. Both measurements have been evaluated by analysing the pattern and correlation over the same period from $1^{\text {st }}$ January 2014 to $31^{\text {st }}$ December 2014.

Based on Figure 9 to 12, all graph pattern indicates a good correlation and agreement between sea level anomaly from satellite altimeter and tide gauge data. It is notable that there is a gap within month of September and October in tide gauge time series as shown in Figure 9 and Figure 11 due to invalid data obtained from UHSLC source. Besides, Figure 10 and 12 illustrate 10 cycles of altimetry SLA data from RADS and PEACHI were used to compare with tidal SLA. The findings show that altimetry data achieves a satisfactory root mean square error (RMSE) with ranging between $0.02 \mathrm{~m}$ and $0.34 \mathrm{~m}$ when compared to the tidal data. The highest RMSE difference obtained is at Cendering station, which is at $0.02 \mathrm{~m}$, and the lowest RMSE difference is at Geting station, which is at $0.34 \mathrm{~m}$. Both tide gauge stations show the correlation analysis, $\mathrm{R}^{2}$ value ranging between -0.111 to 0.727 . The correlation analysis using RADS data better than PEACHI. The correlation analysis between RADS and tide gauge data is acceptable as discussed in [21]. However, there is poor correlation analysis found between PEACHI and tide gauge data may due to altimetry track is too close with tide gauge ( 200 m) and it may have contaminated with land. In contrast, the RMSE between PEACHI and tide gauge data shows a promising findings with less than $0.14 \mathrm{~m}$ for Geting and Cendering station. Table 3 shows the summary of correlation analysis, $\mathrm{R}^{2}$ and RMSE for each station. 


\section{CENDERING}

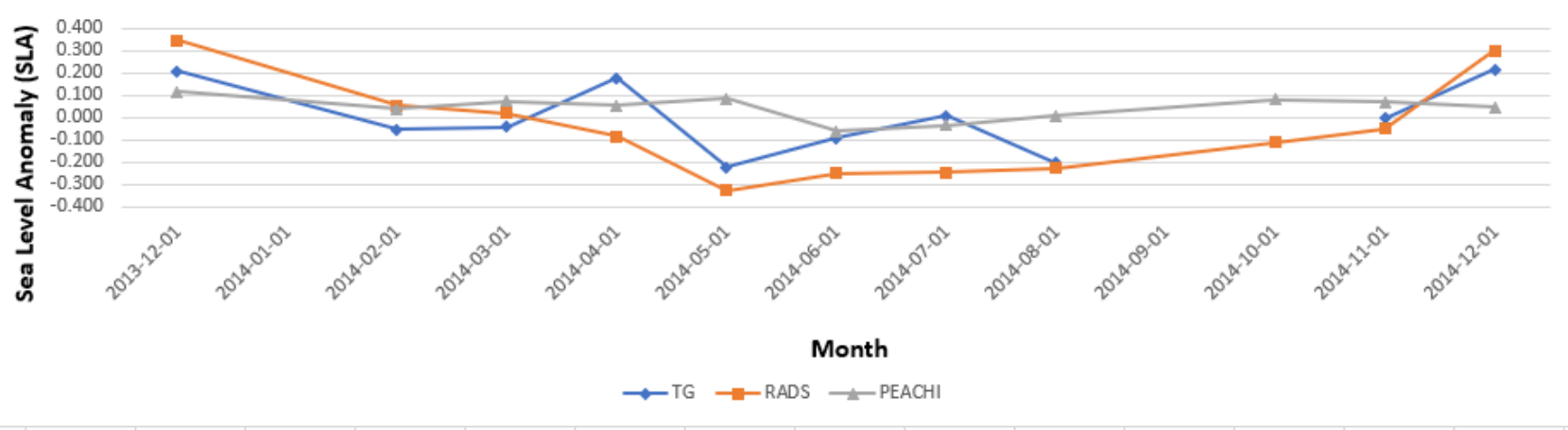

Figure 9 Comparison of time series pattern with hourly sea level anomaly (SLA) from tide gauge (blue), RADS (orange) and PEACHI (grey) at Cendering station (Peninsular Malaysia) using Pass 279 of altimeter track. Units are metre
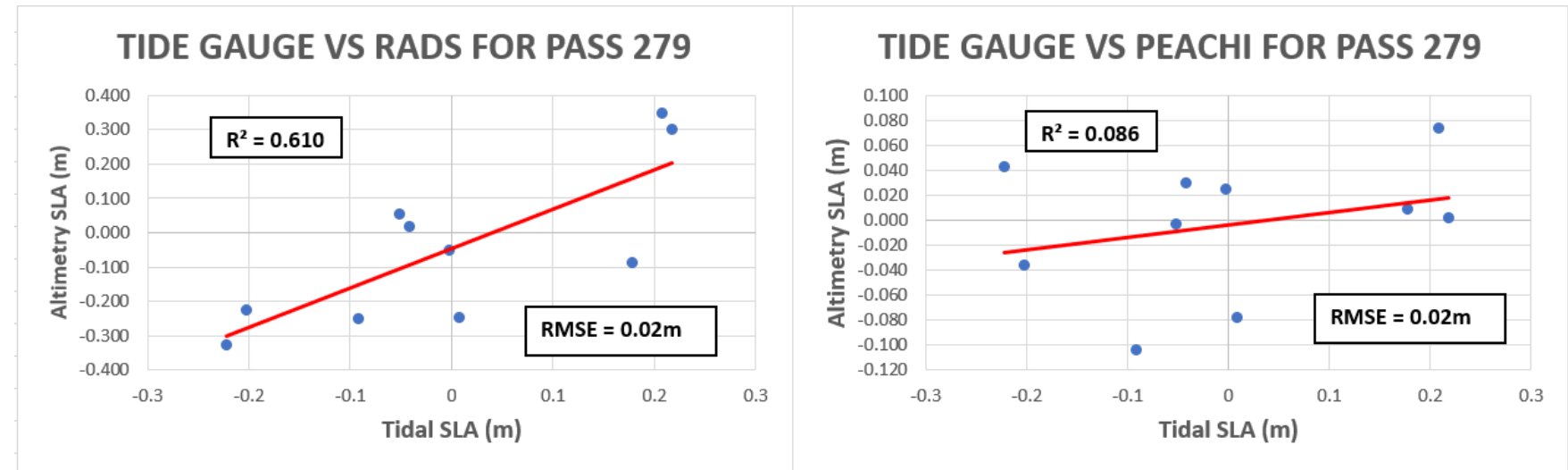

Figure 10 Comparison of correlation analysis, $R^{2}$ and RMSE with hourly sea level anomaly (SLA) from tide gauge versus RADS (left) and tide gauge versus PEACHI (right) at Cendering station (Peninsular Malaysia)

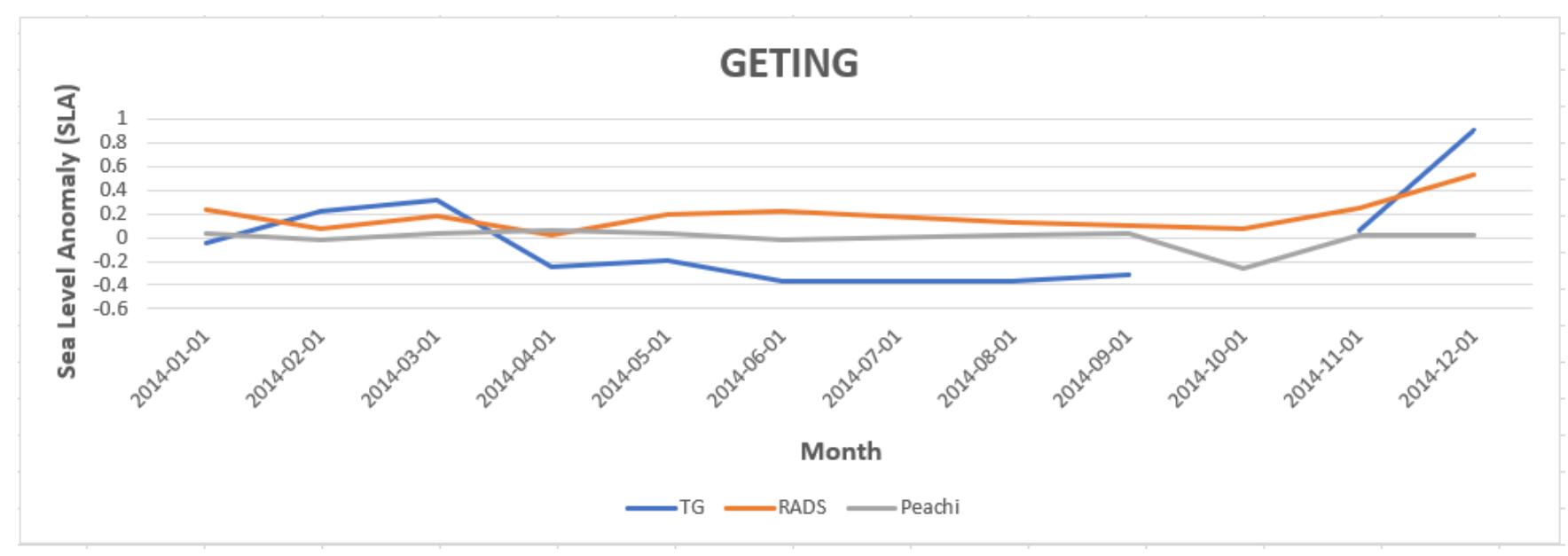

Figure 11 Comparison of time series pattern with hourly sea level anomaly (SLA) from tide gauge (blue), RADS (orange) and PEACHI (grey) at Geting station (Peninsular Malaysia) using Pass 494 of altimeter track. Units are metres 
TIDE GAUGE VS RADS FOR PASS 494

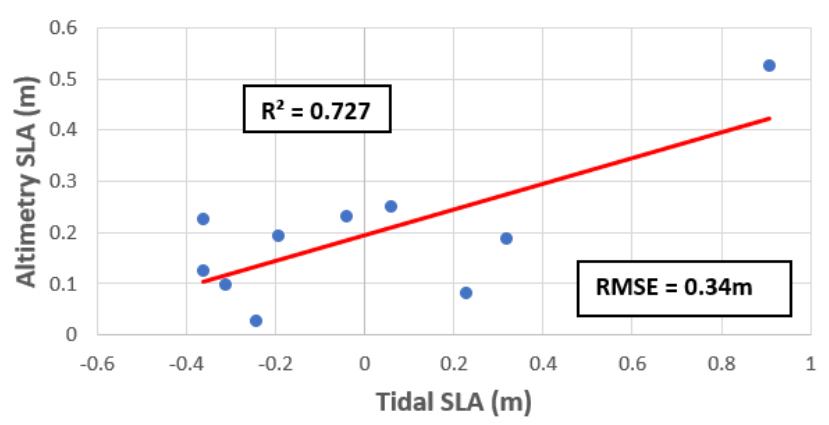

\section{TIDE GAUGE VS PEACHI FOR PASS 494}

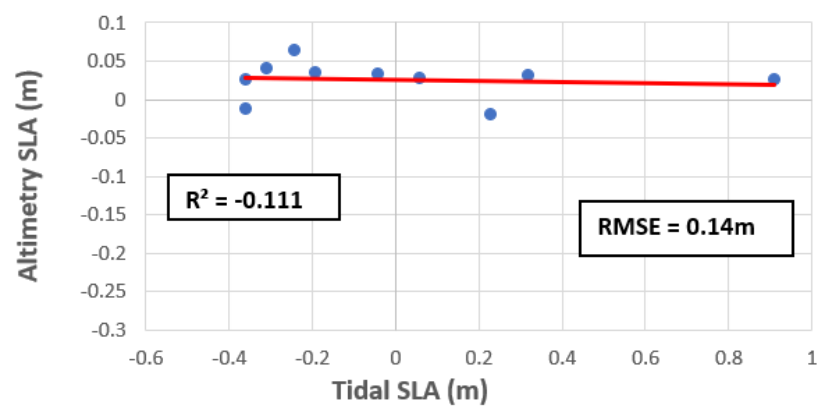

Figure 12 Comparison of correlation analysis, $R^{2}$ and RMSE with hourly sea level anomaly (SLA) from tide gauge versus RADS (left) and tide gauge versus PEACHI (right) at Geting station (Peninsular Malaysia)

Table 3 Summary of correlation analysis, $\mathrm{R}^{2}$ and RMSE at both tide gauge stations for RADS and PEACHI

\begin{tabular}{llllcl}
\hline No & Altimetry & Tide gauge & Pass & Correlation $\left(\mathbf{R}^{\mathbf{2}}\right)$ & RMSE $(\mathbf{m})$ \\
\hline 1 & RADS & Cendering & 279 & 0.610 & 0.02 \\
& & & 494 & 0.727 & 0.34 \\
2 & PEACHI & Geting & 279 & 0.086 & 0.02 \\
& & & 494 & -0.111 & 0.14 \\
\hline
\end{tabular}

\subsection{Sea Level Variation in relating to Distance to Coast}

Next, to extend the assessment of sea level anomaly data from RADS and PEACHI, distance to coast analysis has been performed. The data span used for this analysis is from $1^{\text {st }}$ January 2014 and up to $31^{\text {st }}$ December 2014 as shown in Figure 13 and 14. The area of interest for the analysis of distance to coast as shown in Figure 3 and 4 by using Passes 279 and 494 of altimeter track. Both datasets from low resolution (RADS) and high resolution (PEACHI) are evaluated in relating to the distance to coast by computing the standard deviation of residual for sea level anomaly.
Refer to Figure 13, the result shows that the standard deviation of residual from distance to coast for PEACHI using Pass 279 achieves a satisfactory result with ranging between $0 \mathrm{~cm}$ to $0.52 \mathrm{~cm}$. Meanwhile, standard deviation of residual for RADS data shows a higher variation with ranging between $1.72 \mathrm{~cm}$ to $12.57 \mathrm{~cm}$. The finding provides a similar result to Pass 494 as shown in Figure 14 with RADS data have a higher variation comparing to PEACHI data. The standard deviation of residual for RADS is ranged at $0.34 \mathrm{~cm}$ to $8.44 \mathrm{~cm}$ and PEACHI at $0 \mathrm{~cm}$ to $1.04 \mathrm{~cm}$, respectively. These results may relate to the altimeter footprint with PEACHI data having smaller footprint at $\sim 200 \mathrm{~m}$ interval comparing to RADS data with footprint at $\sim 7 \mathrm{~km}$ interval.

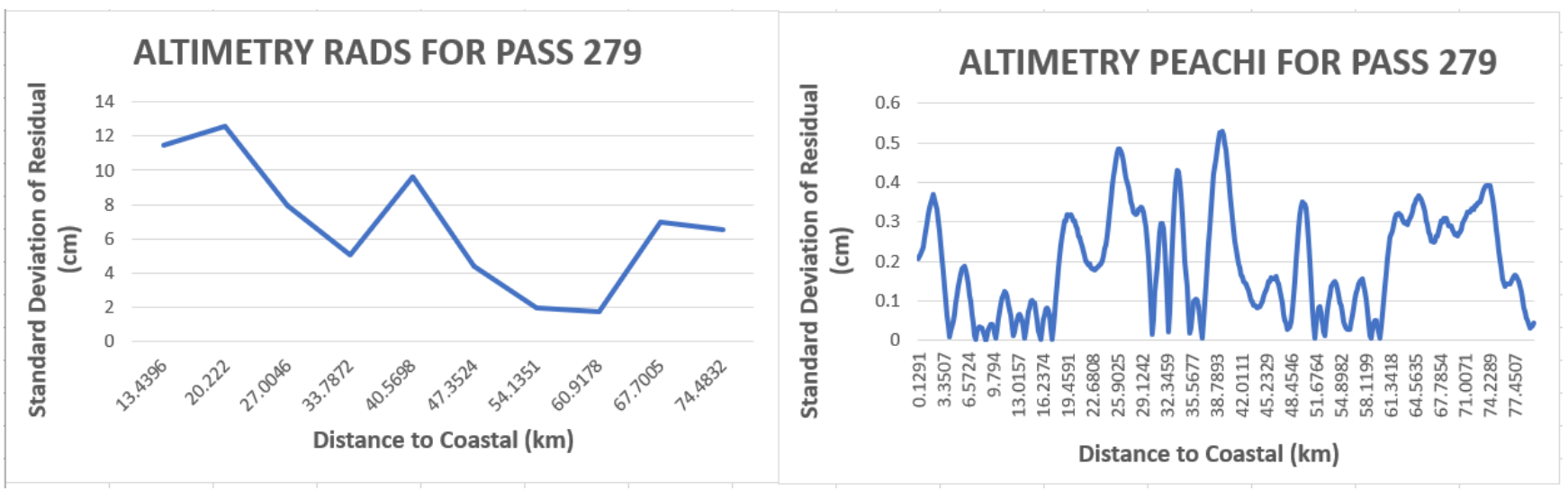

Figure 13 Comparison of standard deviation of residual from distance to coast between RADS (1 Hz) and PEACHI (40 Hz) for Pass 279 

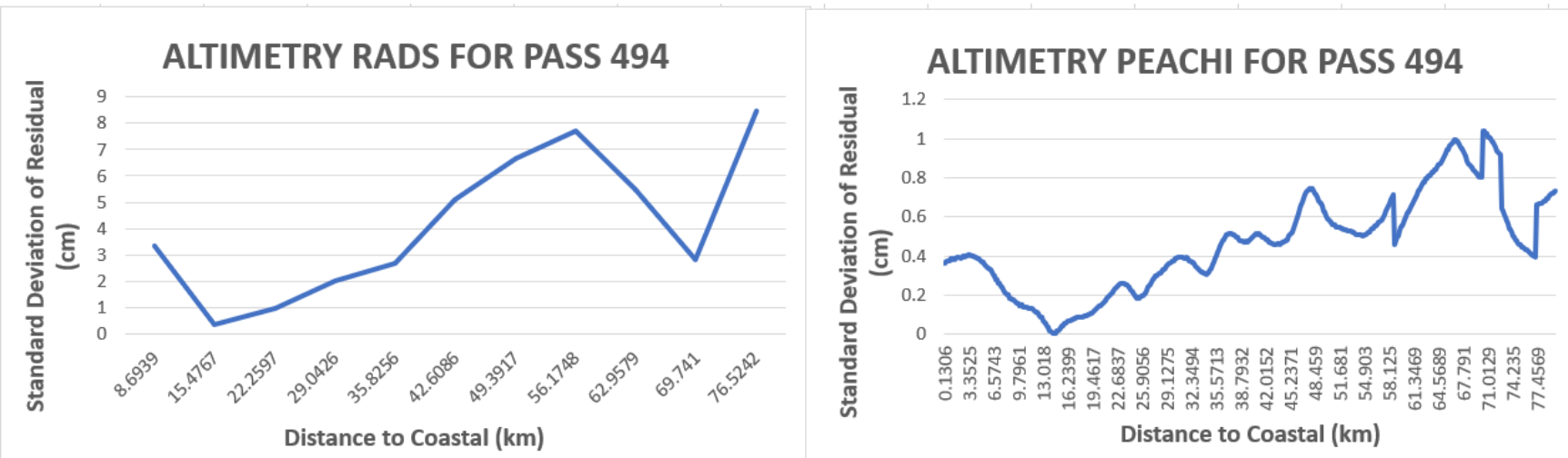

Figure 14 Comparison of standard deviation of residual from distance to coast between RADS (1 Hz) and PEACHI (40 Hz) for Pass 494

\subsection{Sea Level Variation due to Seasonal Effect}

The variability of sea level is contributed by many factors such as global warming, climate and others. However, in Malaysia region, the main factor that clearly affects the sea level variation is the monsoon seasons including Northeast Monsoon, Southwest Monsoon, First-inter Monsoon and Second-inter Monsoon [22]. During these different monsoons, there is different effect of wind and ocean circulation that brings different sea level anomaly pattern.

The climatology of sea level variability from $1^{\text {st }}$ January 2014 to $31^{\text {st }}$ December 2014 is illustrated in Figure 9 and 11. The result shows that sea level variability for east coast of Peninsula Malaysia sea remains below $0.1 \mathrm{~m}$ for RADS, PEACHI and tide gauge data at station Cendering during $1^{\text {st }}$ May 2014 to $31^{\text {st }}$ August 2014. Then, the sea level anomaly at station Geting indicates below $0.23 \mathrm{~m}$ for RADS, PEACHI and tide gauge data during $1^{\text {st }}$ May 2014 to $31^{\text {st }}$ August 2014. It clearly illustrates that the effect of the Southwest Monsoon season which occurs from May to August on the sea level variability. Southwest Monsoon originates from deserts of Australia and signifies a drier season or weather with minimum rainfall throughout the country except for Sabah in east Malaysia [23].

However, the finding shows that the sea level variability indicating a bit higher during Northeast Monsoon in the month of November, December, January and February for both stations; Cendering and Getting (refer to Figure 9 and 11). Northeast monsoon originates in China and north Pacific. Northeast monsoon causes heavy rainfall especially in the east coast of Peninsular Malaysia and western Sarawak [24].

\subsection{Density of Altimetry Data: Low and High Resolution}

This section discusses the density of altimetry data using low and high resolution from RADS and PEACHI, respectively. Figure 15 and 16 summarise the density of altimetry data from RADS (low resolution) and PEACHI (high resolution) within $80 \mathrm{~km}$ from the coast for Passes 279 and 494. The findings can be clearly seen that PEACHI data has denser data comparing to RADS data. This due to the fact that PEACHI has finer footprint (with $\sim 200 \mathrm{~m})$ than RADS $(\sim 7 \mathrm{~km})$. Within $80 \mathrm{~km}$ from the coast, PEACHI can provide around 400 points comparing to RADS only provides around 10 points of altimetry data. The density of altimetry data is important to understand the reliability of the sea level data.

\subsection{CONCLUSION}

Satellite altimeter can provide as a complementary tool to the traditional coastal tide gauge instruments in measuring long-term sea level anomaly, especially in the Malaysia region where the tide gauge stations are still limited both in number and geographic distribution. Through RADS and PEACHI technology, it is able to derive sea level anomaly parameter from low and high resolution of satellite altimetry data. From the finding, the comparison of altimeter data (RADS and PEACHI) and tide gauge observations showed good agreement with RMSE below $0.34 \mathrm{~m}$. Therefore, both altimeter technology and tide gauge techniques are competitive. Meanwhile, PEACHI can provide denser data than RADS due to the high resolution data from PEACHI uses smaller footprint at $\sim 200 \mathrm{~m}$ interval. In conclusion, RADS and PEACHI are extremely helpful in both research and education, and in operational and commercial exploitation of the radar altimeter data products. However, more study and analysis particularly for high resolution of altimetry data is highly recommended due to it is expected that this type of data will benefit a lot particularly for coastal applications in future. 

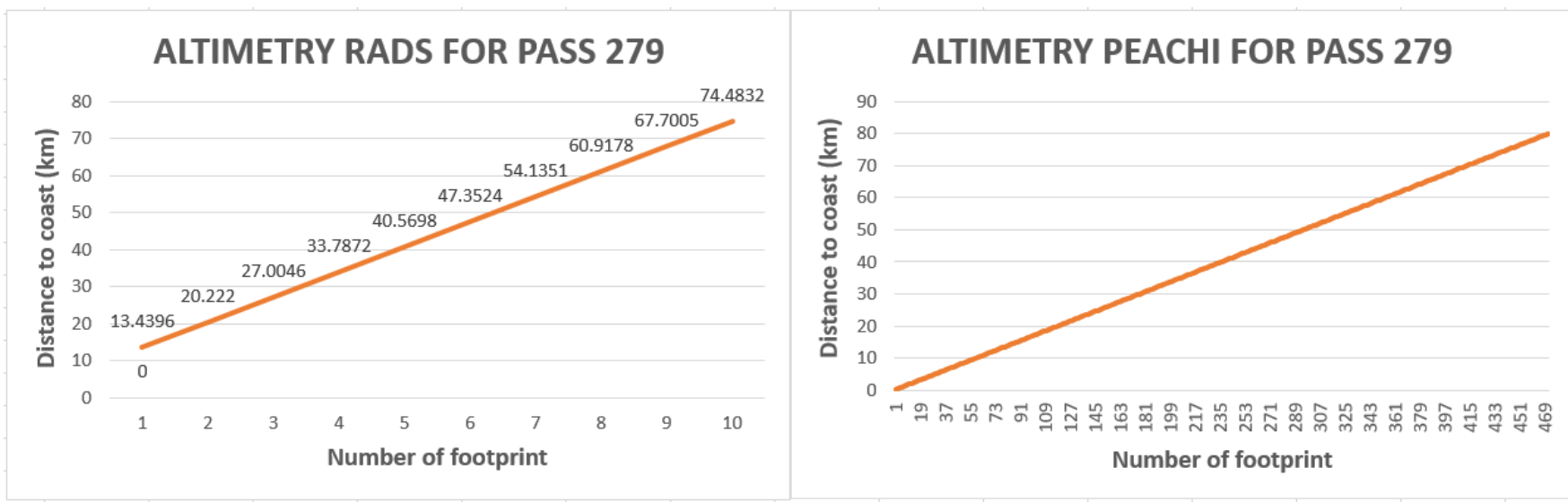

Figure 15 Comparison of altimetry data density between low resolution (RADS) and high resolution (PEACHI) for Pass 279
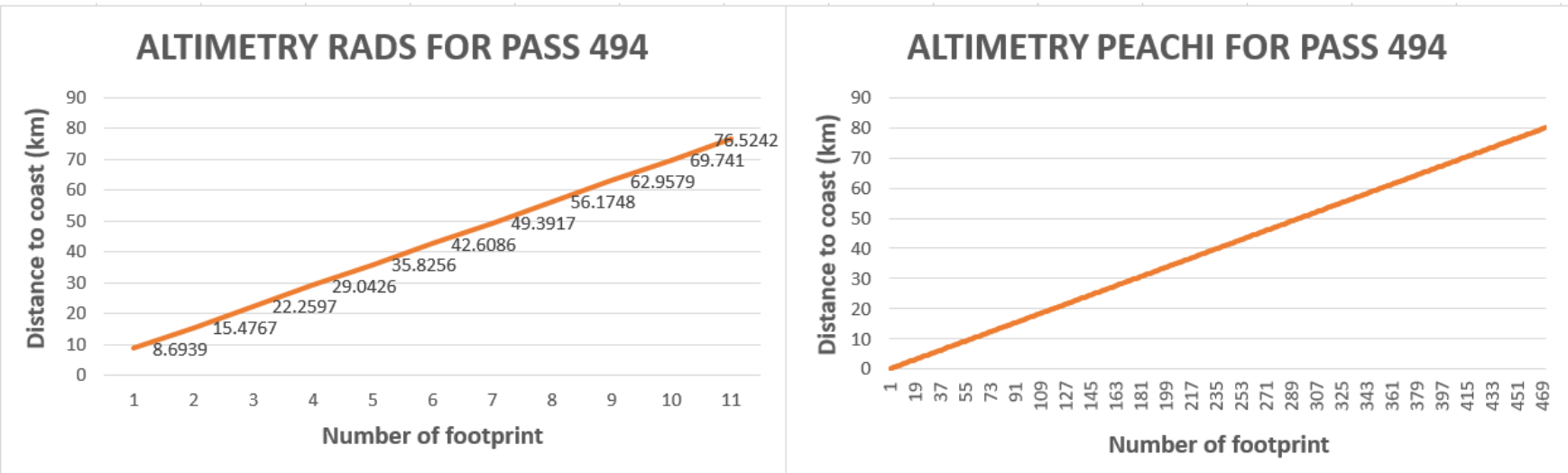

Figure 16 Comparison of altimetry data density between low resolution (RADS) and high resolution (PEACHI) for Pass 494

\section{Acknowledgement}

Special thanks to RADS, PEACHI and UHSLC in providing the altimetry and tidal data. This project is funded by the Ministry of Education (MOE) Malaysia and Universiti Teknologi Malaysia under the Research University Grant (RUG) Tier 2, Vote Number: Q.J130000.2652.16J88.

\section{References}

[1] Luu, Q. H., Tkalich, P., \& Tay, T. W. 2015. Sea Level Trend and Variability around Peninsular Malaysia. Ocean Science. 11 (4): 617-628.

[2] Ehsan, M. R. M., Din, A. H. M., Hamid, A. A. and Adzmi, N. H. M. 2019. Interpretation of Sea Level Variability Over Malaysian Seas Using Multi-mission Satellite Altimetry Data. ASM Science Journal. 12(Issue Special Issue 2): 9099.

[3] Chaudhary, A., Agarwal, N., \& Sharma, R. 2014. Estimation of Currents using SARAL/Altika in the Coastal Regions of India. The International Archives of Photogrammetry, Remote Sensing and Spatial Information Sciences. 40(8): 1365.

[4] Kamaruddin, A. H., Din, A. H. M., Pa'Suya, M. F. and Omar, K. M. 2017. Long-term Sea Level Trend from Tidal
Data in Malaysia. 7th IEEE Control and System Graduate Research Colloquium, ICSGRC 2016 - Proceeding 7813325. 187-192. DOI: 10.1109/ICSGRC.2016.7813325.

[5] Din, A. H. M., Hamid, A. I. A., Yazid, N. M., Tugi, A., Khalid, N. F., Omar, K. M. and Ahmad, A. 2017. Malaysian Sea Water Level Pattern Derived from 19 Years Tidal Data. Jurnal Teknologi. 79(5): 137-145. DOI: 10.11113/jt.v79.9908

[6] Din, A. H. M., Zulkifli, N. A., Hamden, M.H. and Aris, W. A. W 2019. Sea Level Trend Over Malaysian Seas from Multimission Satellite Altimetry and Vertical Land Motion Corrected Tidal Data. Advances in Space Research. 63(1 1): 3452-3472. DOI: 10.1016/j.asr.2019.02.022.

[7] Ratheesh, Smitha, Rashmi Sharma, K. V. S. R. Prasad and Sujit Basu. 2015. Impact of SARAL/AltiKa - Derived Sea Level Anomaly in a Data Assimilative Ocean Prediction System for the Indian Ocean. Marine Geodesy.00-00. doi: 10.1080/01490419.2014.988833.

[8] Troupin, Charles, Ananda Pascual, Guillaume Valladeau, Isabelle Pujol, Arancha Lana, Emma Heslop, Simón Ruiz, Marc Torner, Nicolas Picot and Joaquín Tintoré. 2015. Illustration of the Emerging Capabilities of SARAL/AltiKa in the Coastal Zone using a Multi-platform Approach. Advances in Space Research. 55(1): 51-59. Doi: 10.1016/j.asr.2014.09.011.

[9] Dibarboure, G., Boy, F., Desjonqueres, J. D., Labrove, S., Lasne, Y., Picot, N., Poisson, J.C. \& Thibaut, P. 2014. Investigating Short-wavelength Correlated Errors on Low-resolution Mode Altimetry. Journal of Atmospheric and Oceanic Technology. 31 (6): 1337-1362 
[10] AVISO. 2019. Aviso.altimetry.fr. (2019). Basic Principle: Aviso+. [online] Available at: https://www.aviso.altimetry.fr/en/applications.html [Accessed 9 January. 2019].

[11] Din, A. H. M., Ses, S., Omar, K. M., Naeije, M., Yaakob, O., \& Pa'suya, M. F. 2014. Derivation of Sea Level Anomaly Based on the Best Range and Geophysical Corrections for Malaysian Seas Using Radar Altimeter Database System (RADS). Jurnal Teknologi. 71 (4).

[12] Fu, L., and Cazenave. A. 2001. Satellite Altimetry and Earth Sciences: A Handbook of Techniques and Applications. Academic Press. San Diego, California.

[13] Idris, N. H., Deng, X., Md Din, A. H. and Idris, N. H. 2017. CAWRES: A Waveform Retracking Fuzzy Expert System for Optimizing Coastal Sea Levels from Jason-1 and Jason-2 Satellite Altimetry Data. Remote Sensing. 9(6). Article number 603. DOI: 10.3390/rs9060603.

[14] Wang, X., \& Ichikawa, K. 2017. Coastal Waveform Retracking for Jason-2 Altimeter Data Based on Alongtrack Echograms Around the Tsushima Islands in Japan. Remote Sensing. 9(7), 762.

[15] Gommenginger, C., Thibaut, P., Fenoglio-Marc, L., Quartly, G., Deng, X., Gómez-Enri, J., Challenor, P. \& Gao, Y. 2011 . Retracking Altimeter Waveforms Near the Coasts. Coastal Altimetry. Springer, Berlin, Heidelberg. 61-101.

[16] Google Maps. Malaysia. Accessed May 5, 2019. https://earth.google.com/web/@4.140634,109.6181485, 12.48081884a,2967850.85179216d,35y,Oh,0t,Or/data $=\mathrm{Ch}$ MaEQoJL20vMDIwbW+2GAlgASgC.

[17] RADS. 2019. Radar Altimeter Data Acquisition from RADS: TUDelft. [online] Available at: http://rads.tudelft.nl/rads/data/authentication.cgi.
[18] AVISO+ User Services. 2017. Along-track Level-2+ (L2P) SLA Sentinel-3A Product Handbook. CLS 8-10 rue Hermès Parc Technologique du canal F-31520 Ramonville Cedex France.

[19] AVISO. 2019. Aviso.altimetry.fr. (2019). Basic Principle: Aviso+. [online] Available at: https://www.aviso.altimetry.fr/index.php?id=3116 [Accessed 10 January. 2019].

[20] UHSLC. 2019. Obtaining UHSLC Data: legacy data portal. [online] Available at: http://uhslc.soest.hawaii.edu/data/ [Accessed 9 January. 2019].

[21] Hamid, A. I. A., Din, A. H. M., Hwang, C., Khalid, N. F., Tugi, A. and Omar, K. M. 2018. Contemporary Sea Level Rise Rates Around Malaysia: Altimeter Data Optimization For Assessing Coastal Impact. Journal of Asian Earth Sciences. 166: 247-259. DOI: 10.1016/j.jseaes.2018.07.034.

[22] Deni, S. M., Jemain, A. A., \& Ibrahim, K. 2010. The Best Probability Models for Dry and Wet Spells in Peninsular Malaysia During Monsoon Seasons. International Journal of Climatology. 30(8): 1194-1205.

[23] Suhaila, J., Deni, S. M., Zin, W. W., \& Jemain, A. A. 2010. Trends in Peninsular Malaysia Rainfall Data During the Southwest Monsoon and Northeast Monsoon Seasons: 1975-2004. Sains Malaysiana. 39(4): 533-542.

[24] Husain, M. L., Yaakob, R., \& Saad, S. 1995. Beach Erosion Variability During a Northeast Monsoon: The Kuala Setiu Coastline, Terengganu, Malaysia. Pertanika Journal of Science and Technology. 3(2): 337-348. 